\title{
THE OLD SHADE TREE
}

Before Saskatchewan had a city, A village or a town,

When people dwelt in forts and tents,

And no settlers were around,

There was an interesting incident

Which happened not in vain

In a beautiful white spruce forest

Of the Red Deer River plain.

Grasping, struggling, reaching, striving,

Pushing, stretching, spreading, thriving,

A poplar began to grow.

It pushed up through the mighty evergreens, Struggling the light to see.

By the time of the Riel Rebellion,

The sapling became a tree.

But a fire swept hungrily through the plain,

And the spruce toppled down,

And there in a twisted ugly mess,

They lay rotting on the ground.

Rotting, shrinking, and abating,

Moulding and deteriorating;

But the poplar still did stand.

Among shrubbery, saplings, and alders,

This tree became a king;

And from its stretched leafy branches,

Many birds their songs would sing,

And perhaps beneath those leafy branches,

The moose and elk would roam,

And perchance some lonely Indian

Would set up his tented home;

Wandering, voyaging, tramping;

Traveling, tenting and camping;

And the poplar still did stand.

But a newly married homesteader came In nineteen twenty-eight,

And he built near the mighty poplar

A shack for he and his mate.

The homesteader busily cut trees down,

His yard from the brush to free,

But he did spare the mighty poplar,

And named it - "the old shade tree."

Chipping, chopping, clearing, scrubbing,

Cutting, trimming, slashing, grubbing,

But the shade tree still did stand.
And so it did stand for many a year, And watched the changing scene,

'Til the farmer's land was growing wh Where the poplars once had been;

'Til a rotted log meat house, which bene The old shade tree had stood,

Was at last torn down by the farmer, And was sawed up for fire-wood.

Tearing, breaking, prying, clawing, Wreaking, bucking, splitting, sawing. But the shade tree still did stand.

The farmer's twin sons became naturali And oft the cry would be

"Come look at the bird that is sitting, In the top of the old shade tree."

For many a weary migrant stopped the When through the land did roam, And in the trunk a noisy flicker Did carve out a hollow home. Picking, pecking, knocking, tapping, Drumming, hammering, and rapping But the shade tree still did stand.

The sons began the study of insects, Or entomology;

They collected many specimens, From the trunk of the old shade tree. For the under-wing moths to sugar bait ca And ants lived in the wood, And many beetles of various kinds, Feasted on the sap which flowed. Buprestids, and Elaterids, Tenebroinids, and Cucujids, But the shade tree still did stand.

And so the poplar continued to stand 'Til nineteen fifty-eight,

As the mighty undisputed king Of the homesteader's windbreak.

But then one stormy August afternoor A strong south wind did blow,

It stirred and shook the mighty shade $t$ And to the ground it did go.

Tumbling, toppling, dropping, crashi Falling, splintering and smashing. Gone - it took decades to grow.

- Ron Hooper, P.O. Box 757,

Qu'Appelle, Saskatchewan. SOG $1 S$ 